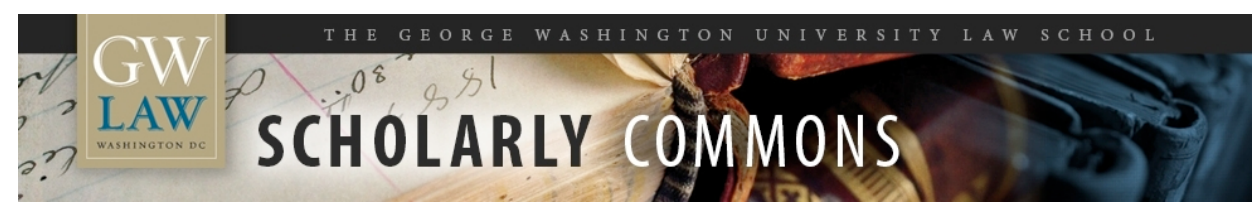

GW Law Faculty Publications \& Other Works

Faculty Scholarship

2019

\title{
Dismantling the Trusts and Estates Canon
}

Naomi R. Cahn

George Washington University Law School, ncahn@law.gwu.edu

Follow this and additional works at: https://scholarship.law.gwu.edu/faculty_publications

Part of the Law Commons

\section{Recommended Citation}

Cahn, Naomi R., Dismantling the Trusts and Estates Canon (2019). Dismantling the Trusts and Estates Canon, 2019 WIS. L. REV. 165 (2019); GWU Law School Public Law Research Paper No. 2019-23; GWU Legal Studies Research Paper No. 2019-23. Available at SSRN: https://ssrn.com/abstract=

This Article is brought to you for free and open access by the Faculty Scholarship at Scholarly Commons. It has been accepted for inclusion in GW Law Faculty Publications \& Other Works by an authorized administrator of Scholarly Commons. For more information, please contact spagel@law.gwu.edu. 


\title{
KEYNOTE LECTURE
}

\section{DISMANTLING THE TRUSTS AND ESTATES CANON}

\author{
NAOMI CAHN*
}

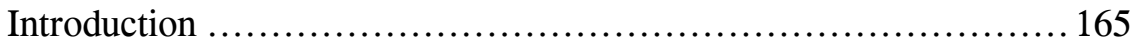

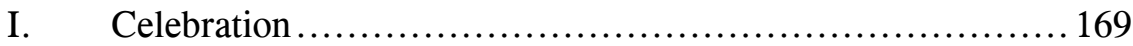

A. Definitions of Property .............................. 170

B. Dead Hand Control and Formalism ...................... 171

C. Definitions of Family .................................. 174

II. Challenge: How Wealth Structures Trusts and Estates ........ 175

A. Structure of Wealth .................................... 176

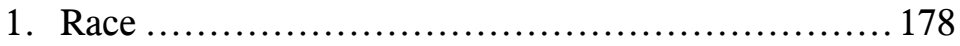

2. Age .......................................... 179

3. Women and Wealth ............................... 181

C. Wealth Has an Impact on Children ..................... 182

D. Using the Preferences of the Wealthy? ................. 185

III. Moving Forward ....................................... 186

A. Trusts and Estates and the Wealth Question ............. 187

1. Wills for All ...................................... 187

2. Intestacy Rules.................................... 188

B. Other Policies ...................................... 189

\section{INTRODUCTION}

The canon of trusts and estates, that is, "the ways of thinking about [trusts and estates] law that are widely shared by legal scholars and especially by legal authorities, like legislators and judges," 1

\footnotetext{
* Associate Dean for Research and Faculty Development and Harold H. Greene Professor of Law, George Washington University School of Law. Thanks to Carla Spivack for her support, to June Carbone and Bridget Crawford for their comments, and to Olivia Soloperto and Christine Kumar for research assistance. Some of the ideas explored in this piece have been developed through work with June Carbone, Nancy Levit, and Amy Ziettlow. I am grateful to the Wisconsin Law Review for making this symposium-and my keynote-possible.

1. Jill Elaine Hasday, The Canons of Family Law, 57 Stan. L. Rev. 825, 825 (2004); see also JiLl E. HaSday, FAmily LAW Reimagined 2-3, 11 (2014) [hereinafter FAmily Law ReIMAgined]; J. M. Balkin \& Sanford Levinson, The Canons of Constitutional Law, 111 HARV. L. REV. 963, 968 (1998) (defining a canon as a discipline's "underlying assumptions, its current concerns and anxieties"). Hasday analyzes family law's canons as "deeply rooted, widely held ways of thinking about family law and its guiding principles that gain strength from their repeated invocation." FAMILY LAW REIMAGINED, supra, at 221. These canons center on "a series of overriding stories that purport to make sense of how the law governs family members
} 
consists of several different and well-known strands: respect for dead hand (or transferor) control (up to certain limits); respect for formality; and valuation of the traditional legally-recognized family. ${ }^{2}$ Perhaps the most fundamental-and, paradoxically, the most visible and invisiblestrand is the "wealth" narrative, which focuses on the transmission of conventional forms of wealth. ${ }^{3}$ It is this final strand that I believe structures the rest of the field.

The wealth narrative is the core of trusts and estates. ${ }^{4}$ Whatever other stories we tell about trusts and estates, whatever challenges we make to the existing strands, concern wealth. While this may seem obvious-another term for the field is "wealth transmission," after allits explanatory power for other canonical stories and for what is left out of those stories is foundational and, in some surprising ways, unacknowledged and unaccounted for. ${ }^{5}$ When we address wealth transmission, we focus on wealth itself, on those who have wealth and their practices, and our guiding assumptions are based on our observations and assumptions about them.

Consider, for example, just why dead hand control is important. Qe respect the dead hand not because we revere the dead, but because the decedent earned, or at least safeguarded, their wealth. Formality is critical to protecting the dead hand's control over wealth and family is, in some ways, yet another form of wealth (consider that fathers were entitled to the earnings from their children's labor). ${ }^{6}$ Our critiques of these principles similarly focus on wealth. Much of the race critique addresses the inheritance of race and problematizes race itself as a form of property. Furthermore, for much of our history, wealth has been concentrated in white married men. Historically, married women were legally limited in property ownership, and blacks could be considered property. ${ }^{7}$ That wealth structure profoundly affected-and affects-

and family life." Id. at 2. As examples of "canonical narratives," she notes the focus on the legal institutions of marriage and parenthood, and argues that such a focus "overlook[s] and offer[s] little protection to other family ties." Id. at 5.

2. See Naomi Cahn \& Amy Ziettlow, "Making Things Fair": An Empirical Study of How People Approach the Wealth Transmission System, 22 ELDER L.J. 325, 326 (2015); see also RAY D. MADOFF, IMMORTALITY AND THE LAW: THE RISING POWER OF THE AMERICAN DEAD 6-7 (2010); Robert H. Sitkoff, Trusts and Estates: Implementing Freedom of Disposition, 58 ST. LouIS U. L.J. 643, 656 (2014).

3. See Cahn \& Ziettlow, supra note 2, at 326-27.

4. See id.; see also Cary Franklin, The New Class Blindness, 128 YALE L.J. 2 (2018) (discussing how substantive due process provides at least some forms of classbased protections).

5. See Cahn \& Ziettlow, supra note 2, at 327.

6. See Jillian Benbow, Under My Roof: Parents' Rights to Children's Earnings, 16 J. CONTEMP. LEGAL IsSUES 71, 71 n.1 (2005).

7. See, e.g., Carole Shammas, Re-Assessing the Married Women's Property Acts, 6 J. Women's Hist. 9, 9 (1994); Adrienne D. Davis, The Private Law of Race 
trusts and estates legislation, practice, and scholarship. Our scholarship powerfully analyzes who is left out of receiving wealth, but we still focus on wealth.

The wealth strand is, accordingly, highly visible, because so much of trusts and estates law is focused on wealth preservation and control, and influential, because its pervasiveness overshadows critical aspects of trusts and estates law. It has also largely been invisible because it serves as a subtle limitation on analyzing issues outside of the process of facilitating wealth transmission. Examining this wealth strand shows how it distorts the field, ${ }^{8}$ so I want to explore just what asking the wealth question, ${ }^{9}$ or using a wealth lens, would actually mean.

Wealth transmission is effectuated, and enforced, through the laws of trusts and estates. Ownership of wealth is a legal matter, but unpacking its influence requires delving into economics and sociology: first, analyzing how wealth transmission also transmits privilege and maintenance of the status quo; second, looking at who has wealth; and third, how recognition of the sociodemographic diversity in ownership of wealth might affect the laws of the trusts and estates field in a variety of ways, ranging from wealth redistribution ${ }^{10}$ to changing the structure of intestate.

To be sure, our scholarly attention is on how trusts and estates policies reinforce some forms of subordination. More profoundly,

and Sex: An Antebellum Perspective, 51 Stan. L. Rev. 221 (1999); Mitchell F. Crusto, Blackness as Property Rights: Sex, Race, Status, and Wealth, 1 STAN. J.C.R. \& C.L. $51,52(2005)$.

8. $\quad C f$., Erez Aloni, The Marital Wealth Gap, 93 WASH. L. REV. 1, 14 (2018) (noting the need to address wealth concentration and family law). As discussed infra, other trusts and estates scholars also apply the wealth lens.

9. Katharine Bartlett famously formulated the "Woman Question":

(1) identifying and challenging those elements of existing legal doctrine that leave out or disadvantage women and members of other excluded groups (asking the "woman question"); (2) reasoning from an ideal in which legal resolutions are pragmatic responses to concrete dilemmas rather than static choices between opposing, often mismatched perspectives (feminist practical reasoning); and (3) seeking insights and enhanced perspectives through collaborative or interactive engagements with others based upon personal experience and narrative (consciousness-raising).

Katharine T. Bartlett, Feminist Legal Methods, 103 HARV. L. ReV. 829, 831 (1990). As Part II discusses, this question can be adapted to ask how our analysis of any doctrine affects people of varying socioeconomic levels; the opportunity to use doctrine to address the actual needs and preferences, rather than presumed or supposed ideals; and the need to draw on alternative perspectives and experiences.

10. As Felix Chang observes, the "laws governing the transmission of wealth are poorly suited to tackle inequality." Felix B. Chang, Asymmetries in the Generation and Transmission of Wealth, 79 OHIO ST. L.J. 73, 78 (2018). Nonetheless, as he also notes, a draconian estate and gift tax system would have significant effects on inequality. Id. at 85-86 (focusing not on gender issues, although mentioning race). See infra notes 117118 for further discussion of tax and inequality. 
however, my argument relies on the observation that the use and transmission of wealth reinforces inequality. ${ }^{11}$ Ensuring that women can serve as executors of estates, ${ }^{12}$ for example, is a victory for gender equality, but directs our focus away from what happens to estates that never appear in probate court and, more fundamentally, from questions of what constitutes wealth and the use of wealth to perpetuate economic and gender inequality.

I want to use this Article to step back and reflect on how new perspectives from gender, race, class, and sexual orientation have challenged existing trusts and estates canonical narratives on a number of different levels, ${ }^{13}$ both in terms of deepening trusts and estates but also expanding it - that is, challenging core concepts of the field. But I also want to urge us to show how what we do as trusts and estates lawyers is related to economic inequality.

Part I celebrates how new perspectives have challenged the core trusts and estates canonical narratives, and builds on the significant analysis of these new perspectives by Bridget Crawford and Anthony Infanti. ${ }^{14}$ As this Article shows, these new perspectives challenge basic concepts of wealth and do the following: 1) bring in alternative conceptions of wealth and of inheritance; 2) question the biases of inheritance law as they reflect conventional social norms; and 3) contextualize the whole field so that it encompasses elder law, history, sociology, socioeconomics, and other areas.

These new perspectives make a difference by causing us to question the intestacy regime, ${ }^{15}$ for example, or by broadening access to wills. ${ }^{16}$ And these challenges are brought both by those of us who

11. See Thomas Piketty, CAPITAL In the Twenty-First Century 378 (Arthur Goldhammer trans.) (2014) ("[W]ealth originating in the past automatically grows more rapidly . . . than wealth stemming from work . . . . [T]his tends to give lasting disproportionate importance to inequalities created in the past, and therefore to inheritance.").

12. See Reed v. Reed, 404 U.S. 71, 76-77 (1971) (holding that unequal treatment on the basis of sex in selecting estate administrators violated the Equal Protection Clause).

13. For a foundational article on these issues, see Bridget J. Crawford \& Anthony C. Infanti, A Critical Research Agenda for Wills, Trusts, and Estates, 49 REAL PROP. TR. \& EST. L.J. 317 (2014).

14. Id.

15. See, e.g., Mary Louise Fellows, Rita J. Simon \& William Rau, Public Attitudes About Property Distribution at Death and Intestate Succession in the United States, 1978 AM. B. Found. RES. J. 319; Mary Louise Fellows, E. Gary Spitko \& Charles Q. Strohm, An Empirical Assessment of the Potential for Will Substitutes to Improve State Intestacy Statutes, 85 IND. L.J. 409 (2010); Adam J. Hirsch, Inheritance on the Fringes of Marriage, 2018 U. ILL. L. REV. 235, 239-40.

16. See Reid Kress Weisbord, Wills for Everyone: Helping Individuals Opt Out of Intestacy, 53 B.C. L. REV. 877, 880-81 (2012). 
identify with the new critical trusts and estates scholarship ${ }^{17}$ and also by people outside of this movement, perhaps because they have been influenced by us, perhaps because of the embedded questions inherent in a focus on transferring wealth.

The second Part turns to the structure of wealth and its intergenerational transmission, drawing on sociological and demographic data to show just who is wealthy and how wealth transmission perpetuates inequality, Finally, based on asking the wealth question, ${ }^{18}$ I suggest future directions that might lead to reexamination of some of the core tenets of trusts and estates: for example, wills may not be appropriate for everyone, and class differences in families show the need to include (or be more deliberate in excluding) alternative families.

Ultimately, for trusts and estates scholarship to call attention to wealth inequality it must broaden its critique. This includes conventional trusts and estates topics, such as calls for improved access to estate planning and higher estate taxes. ${ }^{19}$ But it might also mean advocating for greater equality during lifetime, such as through analysis of a minimum income guarantee. ${ }^{20}$ While this may seem far afield from conventional trusts and estates topics-and it is-income inequality affects trusts and estates practice by defining the core issues and by determining the identity of our clients. At the end, I want to show how this brings us to a new understanding of inheritance.

\section{CELEBRATION}

I begin with a brief celebration of where we are today. My text is not cases, but our own scholarship, as applied to the core canonical stories of trusts and estates law that I identified earlier. A critical trusts and estates jurisprudence has shown how these stories-definitions of property, formalism and dead hand control, and family recognition-

17. See Crawford \& Infanti, supra note 13, at 318 (“[C]ritical scholarship uses an 'outsider' perspective as a lens to examine the substance and structure of the law . . . [by] examining why the law has developed in the way it has and considering what impact the law has on historically disempowered groups . . . .").

18. See supra note 9.

19. See, e.g., Crawford \& Infanti, supra note 13. at 342-47.

20. See Alissa QuART, SQueEzed: Why Our FAMILIES CAN'T AFFORD AMERICA 240-45 (2018); see also Rosalind Dixon \& Julie Suk, Liberal Constitutionalism and Economic Inequality, 85 U. CHI. L. REV. 369, 375 (2018) (noting that "many constitutional democracies . . . are actively considering, and passing, measures to increase investments in education and training, raise the minimum wage, [and] guarantee a universal basic income"). See generally ANNIE LOWREY, GIVE People Money: How a Universal Basic Income Would End Poverty, REVOlUtionize Work, AND REMAKE THE WORLD (2018). 
reflect and reinforce social norms based on race, gender, sexual orientation, and class.

\section{A. Definitions of Property}

As critical jurisprudential trusts and estates scholars have shown, the bundle of sticks ${ }^{21}$ that constitutes property can be parsed, based on race, gender, and other categories. ${ }^{22}$ First, consider that white heirs were able to challenge wills that freed slaves, successfully arguing, for example, that "enslaved blacks were legally classified as immovable property" and so could not be emancipated. ${ }^{23}$ On the other hand, Barack Obama describes how his mother saw being black as being "the beneficiary of a great inheritance." 24

Next, consider limitations on property based on citizenship. Property ownership has historically been tied to citizenship status, and courts in the nineteenth century might prevent noncitizens from inheriting through intestacy, regardless of whether they were closer in relationship to the decedent. ${ }^{25}$ Even today, approximately one-half of states impose restrictions on noncitizens' property ownership rights in some way. ${ }^{26}$ This affects not just the ownership rights of noncitizens, but also those of citizens, whose land alienability is restricted. ${ }^{27}$

21. "Ownership is a bundle of rights, such as the right to exclude others from the property, the right to use the property, the right to sell the property, and so forth." Jessica A. Clarke, Identity and Form, 103 CALIF. L. REV. 747, 829 (2015); see Bela August Walker, Privilege as Property, 42 WASH. U. J.L. \& PoL'Y 47, 54 (2013) (stating that property is a "social category"). The sticks generally constitute: “(a) the right of disposition . . .; (b) the right of possession . . .; (c) the right of control . . .; (d) the right of enjoyment . . .; and lastly, (e) the right of exclusion . . . ." Id.

22. See Cheryl I. Harris, Whiteness as Property, 106 HARV. L. REV. 1707, 1758, 1787-89 (1993); Kevin Noble Maillard, The Color of Testamentary Freedom, 62 SMU L. REV. 1783, 1786 (2009) ("[M]y research shows that white collateral heirs, as both a first and last resort, have leveraged whiteness to contest wills that consciously excluded them.").

23. Crusto, supra note 7, at 106-07.

24. Barack Obama, Dreams from my Father: A Story of RaCe AND INHERITANCE 51 (1995).

25. See Polly J. Price, Alien Land Restrictions in the American Common Law: Exploring the Relative Autonomy Paradigm, 43 AM. J. LEGAL Hist. 152, 155-56 (1999) (discussing Crane v. Reeder, 21 Mich. 24 (1870), in which distant relatives of a deceased landholder successfully challenged the right of closer relatives to inherit on the ground the more immediate heirs were not citizens); Rose Cuison Villazor, Rediscovering Oyama v. California: At the Intersection of Property, Race, and Citizenship, 87 WASH. U. L. REV. 979, 1017 (2010) (discussing citizenship status-based restrictions on inheritance).

26. Allison Brownell Tirres, Property Outliers: Non-Citizens, Property Rights and State Power, 27 GeO. IMMigr. L.J. 77, 97 (2012).

27. Id. at 128. Elsewhere Tirres has argued that "property law [has been used] as a tool of immigration regulation." Allison Brownell Tirres, Ownership Without 
Fourth, until the mid-nineteenth century, women lost rights to property upon marriage. ${ }^{28}$ Even after states enacted Married Women's Property Acts, distinctions remained between free and enslaved women (until the Civil War), ${ }^{29}$ and between married women and men.

Finally, the value of property varies. The decedent's "dress clothes" 30 might fetch little at resale, but could be invaluable to the heirs.

These examples challenge the seemingly neutral concept of property.

\section{B. Dead Hand Control and Formalism}

The testator's intent is most respected when it accords with dominant notions of inheritance; and rights to testamentary freedom depend on social policy. ${ }^{31}$ Although dead hand control is celebrated and the right to control is a form of property, as shown above, the restrictions on who can inherit show the limitations on dead hand control. After the Civil War, anti-miscegenation statutes continued to ensure that blacks could not inherit from white spouses, ${ }^{32}$ and even attempts by white male partners to leave property to children born into their relationship with a black female partner were treated with suspicion. ${ }^{33}$

Citizenship: The Creation of Noncitizen Property Rights, 19 MICH. J. RACE \& L. 1, 4 (2013).

28. See infra Part II.

29. See, e.g., Bernie D. Jones, Southern Free Women of Color in the Antebellum North: Race, Class, and a "New Women's Legal History," 41 AKRON L. REV. 763, 774-75 (2008) ("[S]lave women were denied the legal status that white women had through marriage.").

30. Amy Ziettlow \& NaOmi CAhn, Homeward Bound 5 (2017). Clothes might also be important for burial. $I d$. at 112 (discussing mother's burial in "a real nice Alabama shirt and some jogging pants").

31. See Melanie B. Leslie, Enforcing Family Promises: Reliance, Reciprocity, and Relational Contract, 77 N.C. L. REV. 551, 571, 585 (1999); Carla Spivack, Why the Testamentary Doctrine of Undue Influence Should Be Abolished, 58 U. KAN. L. REV. 245, 308 (2010); Maillard, supra note 22, at 1788.

32. Maillard, supra note 22, at 1792-93 ("Without the protective status that marriage conferred, courts viewed interracial families as inherently illegitimate, which opened estates to the rapacious strategies of white collateral heirs. The reliability of anti-miscegenist amnesia-that is, the narrative that the interracial family does not legally exist-fueled the redirection of testamentary intent.").

33. See, e.g., Davis, supra note 7, at, 280. 
Both husbands and wives were limited by dower and curtesy, until the doctrines' abolition. ${ }^{34}$ Until the Married Women's Property Acts, testators were restricted in what they could bequeath to married women for the women's own use, ${ }^{35}$ and married women faced restrictions themselves on their testation rights. ${ }^{36}$

In 1981, Jeffrey Sherman argued "that the lover-legatee of a homosexual testator faces a more difficult task at probate than does his heterosexual counterpart." 37 Undue influence has been an oft-used means to challenge wills in favor of same-sex partners ${ }^{38}$ and has also been used to challenge other bequests deemed unconventional. ${ }^{39}$

Moreover, dead hand control may reflect, and thus perpetuate, societal discrimination. While charitable bequests can no longer discriminate on the basis of race, some religions may disfavor women, ${ }^{40}$ some estate planning practices (such as the QTIP) may also disadvantage women. ${ }^{41}$

34. See, e.g., Damaris Rosich-Schwartz, Tenancy by the Entirety: The Traditional Version of the Tenancy Is the Best Alternative for Married Couples, Common Law Marriages, and Same-Sex Partnerships, 84 N.D. L. REV. 23, 36 (2008). Moreover, "informal restrictions confined single women's ability" to own property. Laura M. Padilla, Gendered Shades of Property: A Status Check on Gender, Race \& Property, 5 J. GENDER RACE \& JusT. 361, 362 (2002). See generally Carla Spivack, Law, Land, Identity: The Case of Lady Anne Clifford, 87 CHI.-KENT L. REV. 393, 403 (2012) (discussing common law limitations on inheritance of property by females); Allison Anna Tait, The Beginning of the End of Coverture: A Reappraisal of the Married Woman's Separate Estate, 26 YAlE J. L. \& Feminism 165 (2014) (same).

35. See, e.g., Shammas, supra note 7, at 11.

36. See Alfred L. Brophy \& Douglas Thie, Land, Slaves, and Bonds: Trust and Probate in the Pre-Civil War Shenandoah Valley, 119 W. VA. L. REV. 345, 36162 (2016) (" $[\mathrm{M}]$ arried women in Virginia during the period studied here had limited rights to dispose of property at death. This . . . helps explain why property was left to daughters in a legal life estate or in an equitable life estate. Thus, when the daughters passed away they had no property interest, and the property went immediately to their issue.") (citation omitted).

37. Jeffrey G. Sherman, Undue Influence and the Homosexual Testator, 42 U. PitT. L. REV. 225, 246 (1981).

38. See, e.g., Camille M. Quinn \& Shawna S. Baker, Essential Estate Planning for the Constitutionally Unrecognized Families in Oklahoma: Same-Sex Couples, 40 Tulsa L. REV. 479, 501-06 (2005); see E. Gary Spitko, Gone But Not Conforming: Protecting the Abhorrent Testator from Majoritarian Cultural Norms Through Minority-Culture Arbitration, 49 CASE W. RES. L. REV. 275, 278-86, 294314 (1999).

39. See Crawford \& Infanti, supra note 13, at 330-31 (examining gender stereotypes embedded in the doctrine of undue influence).

40. See, e.g., Shelly Kreiczer-Levy, Religiously Inspired Gender-Bias Disinheritance-What's Law Got to Do with It? 43 CREIGHTON L. REV. 669 (2010); Shelly Kreiczer-Levy \& Meital Pinto, Property and Belongingness: Rethinking GenderBased Disinheritance, 21 TEX. J. WoMEN \& L. 119, 148-49 (2011).

41. See Karen J. Sneddon, Not Your Mother's Will: Gender, Language, and Wills, 98 MARQ. L. REV. 1535, 1573-74 (2015) ("Due to life expectancies, QTIPs are 
Even critiques of dead hand control show a wealth bias. As Bridget Crawford points out, some of these analyses suggest that current generations will be better able to manage the wealth they have inherited without restrictions, reflecting a belief in a meritocracy that "ironically allows us to ignore wealth differences." 42

Dead hand control is implemented by respect for the formality attendant to wills. A will expresses not just the testator's wishes, but also commands. Women tend to use precatory language more than men, so a formal written document (which eschews precatory language) may be more likely to translate language into the more directive language that men tend to use. ${ }^{43}$ Indeed, as Karen Sneddon observes, "initial reactions to precatory language and expressive language are tinged with dismissal of 'non-technical language' as 'mere fluff." "44

More fundamentally, while wills do not require lawyers, being able to develop an error-free will that is appropriately channeled depends on the testator's "characteristics, external resources, and [legal and] social environment." ${ }^{45}$ Yet, one study comparing holographic and nonholographic wills found that holographic wills, while more likely to include drafting errors, were no more likely to be challenged. ${ }^{46}$ This raises questions of just how much protection formality provides for testamentary intent as opposed to the other factors that might lead disappointed heirs to challenge a will.

more frequently created for female spouses with the ultimate disposition of the trust property then being directed by the deceased male spouse."). For further commentary on QTIPS and gender bias, see Wendy C. Gerzog, Solutions to the Sexist QTIP Provision, 35 Real Prop. Prob. \& Tr. J. 97, 97-99 (2000); Wendy C. Gerzog, The Marital Deduction QTIP Provisions: Illogical and Degrading to Women, 5 UCLA Women's L.J. 301, 306 (1995). See also Susan M. Chesler \& Karen J. Sneddon, Tales from a Form Book: Stock Stories and Transactional Documents, 78 MoNT. L. REV. 237, 274 (2017) (discussing stock characters in wills).

42. Personal communication, April 2, 2019.

43. See Alyssa A. DiRusso, He Says, She Asks: Gender, Language, and the Law of Precatory Words in Wills, 22 WIS. WoMEN's L.J. 1, 46-47 (2007); Sneddon, supra note 41, at 1551 ("[T]he language of the law itself is male. The ability to shape language 'depends, among other things, on one's apparent legitimacy to engage in that activity.' Those who 'engaged' in the making of the law and the practice of the law before the nineteenth century were exclusively men.") (citations omitted). Kevin Maillard writes about the "legal power of whiteness" with respect to inheritance. Maillard, supra note 22, at 1787-88.

44. Sneddon, supra note 41 , at 1567.

45. Alexander A. Boni-Saenz, Distributive Justice and Donative Intent, 65 UCLA L. REV. 324, 338 (2018).

46. Stephen Clowney, In Their Own Hand: An Analysis of Holographic Wills and Homemade Willmaking, 43 REAL PROP. TR. \& EST. L.J. 27, 59 (2008). 


\section{Definitions of Family}

One of the core concepts in the trusts and estates canon is inheritance through the bloodline. Using a race lens shows us that doctrines are not what they appear to be, and this is intertwined with the previous discussion of definitions of wealth-slave children inherited their status from their mothers, so, upon birth, became property-but also involves the interconnected claims of race and legitimacy that characterized the initial challenges to the inheritance of nonmarital children. ${ }^{47}$ Similarly, LGBTQ legal jurisprudence has questioned the primacy of the bloodline. ${ }^{48}$ Just a few examples follow.

Consider the questions of whether nonmarital children can inherit from their fathers. In the initial state court proceedings that evolved into a "landmark" Supreme Court case involving such rights, ${ }^{49}$ the "lawyers made race as well as sex discrimination arguments when challenging Illinois's inheritance laws in state court, but apparently dropped the race-based disparate impact arguments on appeal to the U.S. Supreme Court." 50 The very question of whether nonmarital children could inherit from their fathers undermines the primacy of the canonical bloodline. ${ }^{51}$

47. Maillard, supra note 22, at 1815-16. Maillard states that:

[T] he larger legal system supports testamentary larceny in blatant contradiction to explicit legal language recognizing, promoting, and memorializing intimate connections between black and white. Testamentary freedom, in all of its aspirational claims, means nothing in the face of a legal system rooted in the restrictive and damaging conformity of 'legitimate' families.

Id. at 1816.

48. See Crawford \& Infanti, supra note 13, at 336-38.

49. Paula A. Monopoli, Toward Equality: Nonmarital Children and the Uniform Probate Code, 45 U. Mich. J.L. REFoRM 995, 999 (2012).

50. Serena Mayeri, Intersectionality and the Constitution of Family Status, 32 Const. Comment. 377, 390 (2017). In Trimble, the Supreme Court struck down parts of Illinois's probate code that allowed nonmarital children to inherit through intestacy from their mothers, but not their fathers, as a violation of equal protection where the classification was based on legitimacy. See Trimble v. Gordon, 430 U.S. 762 (1977). The lower court noted that: "In support of the position that the statutory framework is racially discriminatory, petitioner in cause No. 47092 sets forth various statistical sources which she says indicate that an excessively disproportionate share of illegitimate children were born to blacks and other minorities as compared to Caucasians." In re Estate of Karas, 329 N.E.2d 234, 239 (Ill. 1975).

51. See Linda Kelly Hill, Equal Protection Misapplied: The Politics of Gender and Legitimacy and the Denial of Inheritance, 13 WM. \& MARY J. WOMEN \& L. 129, 147 (2006) (discussing the concept of "filius nullius," under which an "illegitimate child was the child and heir of no one"). 
While these challenges were designed to recognize bloodlines, critical trusts and estates jurisprudence has also challenged the heteronormativity of family definitions. ${ }^{52}$

$$
* * *
$$

Taken together, these critiques challenge core canons, such as dead hand control and the primacy of the bloodline.

\section{Challenge: How Wealth Structures Trusts AND EstateS}

But there is still more to be done as we deepen our critique, and that involves consistently applying a class lens and going beyond traditional trusts and estates topics. Trusts and estates law, scholarship, and practice have generally focused on the wealthy. ${ }^{53}$ That is the population who can pay the bills of estate planning attorneys and who are most likely to write wills; ${ }^{54}$ much of our scholarship focuses on studying the wealth-transmitting population, mistakes made by their attorneys, how better to effectuate the intent of that population, to whom they leave-and do not leave-property, etc. Of course, even that population is "heterogeneous, and many middle-class individuals make arrangements for property after their deaths, even if that property is more modest-for example, a small family home or a collection of heirlooms." 55 But more than half of the population does not write wills ${ }^{56}$ most low-income Americans have no money saved for retirement, ${ }^{57}$ approximately $40 \%$ of Americans do not have life insurance, ${ }^{58}$ and almost two-thirds have not planned for incapacity. ${ }^{59}$

52. See Crawford \& Infanti, supra note 13, at 335-37 (documenting the work of E. Gary Spitko, Tom Gallanis, and Mary Louise Fellows, among others).

53. See Boni-Saenz, supra note 45, at 329.

54. Older white people with a graduate degree are the most likely to have wills. See Jeffrey M. Jones, Majority in U.S. Do Not Have a Will, GalluP (May 18, 2016), [https://perma.cc/U5VC-CHM5]. https://news.gallup.com/poll/191651/majority-not.aspx

55. Boni-Saenz, supra note 45, at 329; see David Horton, Intestacy, Wills, and Intent: A Short Comment on Wright \& Sterner, 43 ACTEC L.J. 339, 342 (2018) (noting heterogeneity of wills).

56. Nick DiUlio, More Than Half of American Adults Don't Have a Will, 2017 Survey Shows, CARING.COM, https://www.caring.com/articles/wills-survey-2017 [https://perma.cc/7A9K-XRBT]; Jones, supra note 54.

57. See Monique Morrissey, The State of American Retirement, Econ. PoL'Y INST. (Mar. 3, 2016), https://www.epi.org/publication/retirement-in-america/\#charts [https://perma.cc/2JLR-33N6] ("In 2013, nearly nine in [ten] families in the top income fifth had retirement account savings, compared with fewer than one in [ten] families in the bottom income fifth.").

58. New Study Reveals More than 40 Percent of Americans Don't Have Any Form of Life Insurance, Мкт. WATCH (Sept. 4, 2018 10:00 AM), 
We use the preferences of those who die with wills to make recommendations for those who die intestate and whose property passes outside of probate courts. ${ }^{60}$ Indeed, further study of how inheritance happens outside of probate court is needed, ${ }^{61}$ and there is a need for more scholarship on non-financial issues, such as the guardianship of children, ${ }^{62}$ at death or incapacity.

As this Part shows, wealth functions in trusts and estates at different levels. A first issue, discussed above, is just what constitutes wealth. Second is looking at how wealth is distributed and who is thus more likely to engage in estate planning. Third is the relationship between wealth transmission and economic inequality. This Section turns first to address the socioeconomics of wealth, that is, who has wealth, and then turns to the deeper structure of wealth in our society, how having wealth reinforces economic inequality. It then shows the impact of wealth on intergenerational mobility, and finally, how asset transmission contributes to intergenerational wealth inequality. The final part concludes by using this analysis to argue for the need for greater self-consciousness and acknowledgement of the potential for bias that results from relying on the preferences of those people who leave records.

\section{A. Structure of Wealth}

The conventional definition of wealth is financial and we live at a time of increasing economic inequality, in which wealth accumulation is increasingly concentrated in a smaller percentage of the population

https://www.marketwatch.com/press-release/new-study-reveals-more-than-40-percentof-americans-dont-have-any-form-of-life-insurance-2018-09-04

[https://perma.cc/MYW7-RWTN]; Peter R. Orszag, The Decline of Life Insurance Is a Mystery, BLOOMBERG (Feb. 27, 2018, 4:30AM CST), https://www.bloomberg.com/opinion/articles/2018-02-27/the-decline-of-life-insuranceis-a-mystery ("The share of Americans with life insurance has fallen to less than 60 percent, from 77 percent in 1989.”).

59. Carolyn Crist, Over One Third of U.S. Adults Have Advanced Medical Directives, REUTERS (July 11, 2017 5:11 PM), https://www.reuters.com/article/ushealth-usa-advance-directives/over-one-third-of-u-s-adults-have-advanced-medicaldirectives-idUSKBN19W2NO [https://perma.cc/C99F-4YXB].

60. See infra note 116.

61. Studying these issues is, of course, difficult. For some of this work, see Mary Louise Fellows, supra note 15 (intestacy), Cahn \& Ziettlow, supra note 2; DiRusso, supra note 43, and Hirsch, supra note 15.

62. $C f$. Deirdre M. Smith, Keeping It in the Family: Minor Guardianship as Private Child Protection, 18 ConN. PUB. INT. L.J. (forthcoming) (draft at 6-7), https://papers.ssrn.com/sol3/papers.cfm?abstract id $=3349167$ (noting the lack of scholarship relating to minor guardianships as used in child protection proceedings). 
that depends less on wages and more on investment income. ${ }^{63}$ Thus, assets that are inherited are critically important in maintaining and building wealth. The term "wealth" refers to any assets, ranging from bank accounts to stocks to real property; it is thus different from income, which, until it becomes wealth, is transitory and is an ongoing flow (that, obviously, stops at death) ${ }^{64}$ Both wealth and income provide measures of economic status and inequality ${ }^{65}$ (although wealth preservation is the focus of many trusts and estates practitioners).

Some of the wealth structure statistics are straightforward, and they document the gap between wealthy and non-wealthy families. In 1978 , the $0.1 \%$ richest families owned $7 \%$ of the country's wealth; by 2012 , that had grown to $22 \%{ }^{66}$ Taking a broader measure of wealth families, the median upper-income family (those who make more than $\$ 127,600$ ) now holds 75 times the wealth of the median low-income family (those who make less than $\$ 42,500$ ); in 2007, top earners were worth 40 times as much; and in 1989 , the multiple was $28 .^{67}$ The bottom half, based on household income, of the American population owned about $1.2 \%$ of total wealth, while the top $1 \%$ of households owned more than $38 \%$ of the wealth. ${ }^{68}$

\footnotetext{
63. See Nelson D. Schwartz, The Recovery Threw the Middle-Class Under a Benz, N.Y. TIMES (Sept. https://www.nytimes.com/2018/09/12/business/middle-class-financial-crisis.html [https://perma.cc/FQ32-GSMQ] ("[T]he proportion of family income from wages has dropped from nearly $70[\%]$ to just under $61[\%] . ")$.

64. See Aloni, supra note 8, at 7-9 (2018) (defining wealth and income, and noting that wealth is capable of transfer and sale); Angela Hanks, Danyelle Solomon \& Christian E. Weller, Systematic Inequality: How America's Structural Racism Helped Create the Black-White Wealth Gap, CTR. FOR AM. Progress (Feb. 21, 2018 9:03 $\mathrm{AM})$, https://www.americanprogress.org/issues/race/reports/2018/02/21/447051/systematicinequality/ [https://perma.cc/X83A-CFJ3].

65. See Drew DeSilver, The Many Ways to Measure Economic Inequality, PEW RESEARCH CTR. (Sept. 22, 2015), http://www.pewresearch.org/facttank/2015/09/22/the-many-ways-to-measure-economic-inequality/

[https://perma.cc/UB4X-7LEW] (discussing income, consumption, and household wealth and noting " $[\mathrm{m}]$ ost researchers agree that wealth is more unevenly distributed than income, while consumption is less concentrated at the upper end than either wealth or income").

66. Emmanuel Saez \& Gabriel Zucman, Nat'l Bureau of Econ. , Wealth Inequality in the United States Since 1913: EvidenCE From CAPiTAlized INCOME TAX DATA 1 (2014), https://www.nber.org/papers/w20625.pdf [https://perma.cc/7MTT-ETSC].

67. Lydia DePillis, America's Wealth Gap is Bigger than Ever, CNN Bus. (Nov. 3, 2017, 4:09 PM), https://money.cnn.com/2017/11/03/news/economy/wealthgap-america/index.html [https://perma.cc/98ZS-QR47].

68. Wealth Distribution in the United States in 2016, Statista (July 2018), https://www.statista.com/statistics/203961/wealth-distribution-for-the-us/ [https://perma.cc/E7SF-5JW9].
} 
At the same time, turning to income, there is a growing earnings gap between the college and non-college educated. ${ }^{69}$ And the gap in weekly wages between the top and bottom is increasing. ${ }^{70}$ By 2016, the average CEO pay at top companies was 361 times as high as median worker income; in the late 1950s, it was approximately 20 times. $^{71}$

Yet these overall statistics mask significant differences by race, ethnicity, gender, marital status, and age.

\section{RACE}

Income and wealth vary by race and between races. ${ }^{72}$ Consider that Asians earn more than any other group, and yet their income inequality is also higher than any other group. ${ }^{73}$

When it comes to wealth distribution, "blacks between 50 and 65 years old and near retirement had only about $10 \%$ of the wealth of whites in the same age group."74 Indeed, "African Americans have fewer assets than whites and are less likely to be homeowners, to own

69. The Rising Cost of Not Going to College, Pew Ctr. (2014), http://www.pew.org/wp-content/uploads/sites/3/2014/02/SDT-higher-ed-FINAL-02-112014.pdf [https://perma.cc/KAA6-H3K7].

70. Naomi Cahn, June Carbone \& Nancy Levit, Gender and the Tournament: Reinventing Antidiscrimination Law in an Age of Inequality, 96 TEX. L. REV. 425, 455 (2018); see also Drew DeSilver, For Most U.S. Workers, Real Wages Have Barely Budged in Decades, PEw RES. CTR. (Aug. 7, 2018), http://www.pewresearch.org/facttank/2014/10/09/for-most-workers-real-wages-have-barely-budged-for-decades/ [https://perma.cc/QW44-CBRW].

71. Diana Hembree, CEO Pay Skyrockets to 361 Times that of the Average Worker, FORBES (May 22, 2018, 04:28pm), https://www.forbes.com/sites/dianahembree/2018/05/22/ceo-pay-skyrockets-to-361times-that-of-the-average-worker/\#173128fe776d [https://perma.cc/U4PU-MSNV]; see Benjamin F. Mitchell, Report: CEO Pay More Than 300 Times Average Workers in 2014, USA TODAY (June 21, 2015, 7:02PM), https://www.usatoday.com/story/money/2015/06/21/epi-report-ceo-pay-303-timesaverage-2014/29000333/ [https://perma.cc/BPW7-RM4X]. As with other sectors, the disparities between top firms and others often exacerbate differences in compensation. See Executive Paywatch: High-Paid CEOs and the Low-Wage Economy, AFL-CIO, http://www.aflcio.org/Corporate-Watch/Paywatch-2014 [https://perma.cc/4WS2NCF6].

72. See Anthony Cilluffo \& Rakesh Kochhar, How Wealth Inequality Has Changed in the U.S. Since the Great Recession, by Race, Ethnicity and Income, PEW RES. CTR. (Nov. 1, 2017), http://www.pewresearch.org/fact-tank/2017/11/01/howwealth-inequality-has-changed-in-the-u-s-since-the-great-recession-by-race-ethnicityand-income/ [https://perma.cc/7R3N-FZVN].

73. Rakesh Kochhar \& Anthony Cilluffo, Key Findings on the Rise in Income Inequality Within America's Racial and Ethnic Groups, PEW RES. CTR. (July 12, 2018), http://www.pewresearch.org/fact-tank/2018/07/12/key-findings-on-the-rise-in-incomeinequality-within-americas-racial-and-ethnic-groups/ [https://perma.cc/J5DH-L98W].

74. Hanks et al., supra note 66. 
their own business, and to have a retirement account." 75 Moreover, even when these types of assets were owned by blacks, their value was still much lower than comparable assets owned by whites. ${ }^{76}$ Blacks and Hispanics were significantly less likely than whites to have savings outside of a retirement account to provide them funds when they retired and were somewhat less likely to have Social Security. ${ }^{77}$

\section{AGE}

The poverty rate for older people is comparatively low, at about $8 \%$, although a larger number are economically insecure, and, in line with the rest of the population, their rates are not increasing, but their numbers are growing. ${ }^{78}$ Moreover, overall poverty rates for older people mask the differences based on marital status, race, gender, and other factors. Indeed, the National Institute on Retirement Security reported that women who are sixty-five and older have incomes that are $25 \%$ lower than men's of the same age, and that the women are $80 \%$ more likely than men to be impoverished. ${ }^{79}$

The general poverty rate for older Americans who are living alone (or with nonrelatives) is $18 \%{ }^{80}$ Married women who are 65 and older have a low poverty rate ( $2 \%)$, particularly compared to the poverty rates for widowed $(13 \%)$, divorced $(16 \%)$, and never-married women $(18 \%){ }^{81}$ Turning to those specifically affected by grey divorce, women

75. Id.

76. See id.

77. Report on the Economic Well-Being of U.S. Households in 2017 - May 2018, FED. RESEARCH BD., https://www.federalreserve.gov/publications/2018economic-well-being-of-us-households-in-2017-retirement.htm [https://perma.cc/QA3X-Z79H].

78. See Poverty Rate by Age, KAISER FAMILY Found, https://www.kff.org/other/state-indicator/poverty-rate-by-

age $/$ ?currentTimeframe $=0 \&$ sortModel $=\% 7 \mathrm{~B} \% 22$ colId $\% 22: \% 22$ Location $\% 22, \% 22$ sort \% 22:\%22asc\%22\%7D [https://perma.cc/7PRL-SENN].

79. Women $80 \%$ More Likely to Be Impoverished in Retirement, NAT'L INST. ON RET. SEC. (Mar. 1, 2016), https://www.nirsonline.org/2016/03/women-80-morelikely-to-be-impoverished-in-retirement/ [https://perma.cc/9JQF-LTGC].

80. Ashley Edwards et al., Outlying Older Americans: The Puzzle of Increasing Poverty Among Those 65 and Older, U.S. Census Bureau: Census Blogs (Sept. 12, 2017), https://www.census.gov/newsroom/blogs/randomsamplings/2017/09/outlying_older_ameri.html [https://perma.cc/H3LF-RRZ7].

81. Steven A. SASS, CTR. FOR RetiRement Research, How Work \& Marriage Trends Affect Social Security's Family Benefits 5 (2016), http://crr.bc.edu/wp-content/uploads/2016/06/IB_16-9.pdf [https://perma.cc/UF5VBW7S]. 
are more than twice as likely as men to be poor (27\% compared to $11 \%){ }^{82}$

The higher rates for divorced and never-married women probably reflect selection effects rather than a marriage bonus per se: nonmarital and divorce rates are higher among groups that typically have lower lifetime earnings and retirement incomes. ${ }^{83}$

Social Security provides benefits during retirement to qualified workers, and the Social Security system is responsible for ensuring that almost a third of people over age sixty-five are not poor ${ }^{84}$ While Social Security is available to employees who have worked for ten or more years, individuals can claim based either on their own work record or on that of a spouse or (with certain limitations) a former spouse; a spouse is entitled to $50 \%$ of the amount that the other spouse would receive, and even if a spouse's own benefits are less than that amount, they will be "topped up." 85

82. See I-Fen Lin, Susan L. Brown \& Anna M. Hammersmith, Marital Biography, Social Security, and Poverty, 39 Res. ON AgIng 86, 98 (2016). Jocelyn Elise Crowley labels these consequences the gray divorce penalty. JOCELYN ELISE Crowley, Gray Divorce: What We Lose and Gain from Mid-Life Splits 17 (2018). She notes that women face financial penalties because of their childrearing responsibilities and workforce patterns; men experience a "social" penalty because they have less robust social support. $I d$.

83. See generally June CARBOne \& NAOMI CAHN, MARRIAGE MARKETS: How INEQUALITY IS REMAKING THE AMERICAN FAMILY (2014) (reporting on the class divergence in marriage rates).

84. Kathleen Romig, Social Security Lifts More Americans Above Poverty than Any Other Program, CTR. ON Budget \& Pol'y PRIORITIES (Nov. 5, 2018), https://www.cbpp.org/research/social-security/social-security-keeps-22-millionamericans-out-of-poverty-a-state-by-state [https://perma.cc/G5G4-4HXS]; Teresa Ghilarducci, Bridget Fisher \& Zachary Knauss, Now is the Time to Add Retirement Accounts to Social Security: The Guaranteed Retirement Account Proposal, ScHWARTZ CTR. FOR ECON. POL'Y ANALYSIS, at 4 (June 2015), http://www.economicpolicyresearch.org/images/docs/retirement_security_background/ GRA_3.0.pdf [https://perma.cc/9MGY-SPG7].

85. Indeed, if one spouse is the primary or sole wage earner, the other spouse can receive Social Security even though that spouse has not paid into the system. lines. See SASS, supra note 81, at 2 ("Spousal benefits guarantee the wife a Primary Insurance Amount (PIA) [] equal to half her husband's PIA. . . . If a woman is eligible for a worker benefit based on her own earnings history that exceeds the spousal [] benefit, she will receive the larger amount. If her worker benefit is lower, then she is 'topped up' to the level of the spousal or survivor benefit"). With increasing divorce and nevermarried rates, however, the number of people able to claim on their spouse's earnings is decreasing, particularly for nonwhite populations. See Tom Anderson, Married Couples Have 81 Ways to Claim Social Security. Here's How to Maximize Your Benefits, CNBC (June 4, 2017, 11:01 AM), https://www.cnbc.com/2017/06/02/howmarried-couples-can-maximize-their-social-security-benefits.html [https://perma.cc/KV5W-GS9R]; Soc. Sec. Admin., Marriage Trends And Women's BENEFITS: DIFFERENCES BY RACE-ETHNICITY AND NATIVITY (2014), https://www.ssa.gov/policy/docs/research-summaries/marriage-trends-raceethnicity.pdf html [https://perma.cc/TA4V-4H3R]. 
$84 \%$ of Americans sixty-five and older receive benefits, with more than $60 \%$ of Social Security beneficiaries receiving one-half or more of their income through such benefits. ${ }^{86}$ Notably, $34 \%$ of all beneficiaries receive almost all (at least $90 \%$ ) of their income from Social Security. ${ }^{87}$ There are significant variations by race. Black, Hispanic, and Asian seniors are more likely to rely on Social Security benefits as their sole source of income, at rates of $32 \%, 40 \%$, and $26 \%$ (respectively), while for whites, it is $18 \%{ }^{88}$ Marital status also has an impact: about $48 \%$ of married couples, and $71 \%$ of unmarried individuals, receive one-half or more of their income from SSA. ${ }^{89}$ Disability and sexual orientation also create significant disparities. With changes in retirement plans, longer lifespans and higher costs for health care, "these high rates of reliance on Social Security benefits are not surprising." 90 Nor is the rise in household debt and grey bankruptcy unexpected ${ }^{91}$ - the high reliance on Social Security also indicates the comparative lack of wealth among these groups.

\section{WOMEN AND WEALTH}

The numbers on women and wealth are more difficult to collect, with differing estimates depending on the age group (and source). Globally, women hold $30 \%$ of private wealth, and constitute $10 \%$ of the wealthiest individuals. ${ }^{92}$ By 2020 , they are expected to hold $\$ 72$ trillion, or $32 \%$ of the total. ${ }^{93}$ One report on women in the United

\footnotetext{
86. Soc. Sec. Admin., Fast Facts \& Figures About Social Security, $2017 \quad$ at $\quad 8 \quad$ (2017), https://www.ssa.gov/policy/docs/chartbooks/fast_facts/2017/fast_facts17.pdf [https://perma.cc/9PM2-HVSU].

87. Id. at 8 .

88. See Social Security and People of Color, NAT'L ACAD. Soc. InS., https://www.nasi.org/learn/socialsecurity/people-of-color [https://perma.cc/2YR2AYP6] (reporting on 2014 data).

89. See Soc. SEC. Admin., supra note 86, at 7.

90. Francine J. Lipman \& James E. Williamson, Social Security Retirement Benefits: A Timing Model for Working Families 14 NAELA 1, 2 (2018).

91. Deborah Thorne, Pamela Foohey, Robert M. Lawless \& Katherine M. Porter, Graying of U.S. Bankruptcy: Fallout from Life in a Risk Society 11 (Indiana Legal Studies Res. Paper No. 406, 2018), https://papers.ssrn.com/sol3/papers.cfm?abstract_id=3226574 (finding an almost a five-fold increase over the past 25 years).

92. Women's Wealth Is Rising, ECONOMIST (Mar. 8, 2018), https://www.economist.com/graphic-detail/2018/03/08/womens-wealth-is-rising [https://perma.cc/VF8C-Y4QU].

93. Investment by Women, and in Them, Is Growing, ECONOMIST (Mar. 8, 2018), https://www.economist.com/finance-and-economics/2018/03/08/investment-bywomen-and-in-them-is-growing [https://perma.cc/ZA2U-RNTK].
} 
States estimates that women own $51 \%$ of American private wealth. ${ }^{94}$ By contrast, another report estimates that women control approximately one-fifth of US wealth. ${ }^{95}$ Nonetheless, based on census household values, women age sixty-five and over who are heads of households have a higher net worth than male householders. ${ }^{96}$ Moreover, because women are statistically more likely to live longer than men and men are likely to earn more than women, widows may accumulate more money when their spouses die. Of course, this statistic must be tempered by the recognition that these widows are also likely to incur health care costs and their wealth may take the form of trusts to which they have relatively limited access.

\section{Wealth Has an Impact on Children ${ }^{97}$}

Stanford economist Raj Chetty, a leading expert on social mobility, found that millennials born in the 1980s are less likely than their parents were to out-earn their parents. ${ }^{98}$ For black and Native

94. BMO Wealth InSt., Financial Concerns of Women 2 (2015), https://www.bmo.com/privatebank/pdf/Q1-2015-Wealth-Institute-Report-FinancialConcerns-of-Women.pdf [https://perma.cc/N5E7-D4NE].

95. Reshma Kapadia, The Stubborn Wealth Gap Between Men and Women, BARRON's (Apr. 18, 2018), https://www.barrons.com/articles/the-stubborn-wealth-gapbetween-men-and-women-1524099601 [https://perma.cc/9FTH-PE4P] (finding household net worth in the U.S. in 2017 "was almost \$100 trillion in the fourth quarter of 2017, according to the Federal Reserve" and that "[b]y 2020, women are expected to control $\$ 22$ trillion of it").

96. Wealth, Asset Ownership, \& Debt of Households Detailed Tables: 2013, U.S. CENSUS BUREAU (Sept. 17, 2018), https://www.census.gov/data/tables/2013/demo/wealth/wealth-asset-ownership.html [https://perma.cc/UM5U-2CR6].

97. Probability of Children's Income Level, Given Parents' Income Level, The Hamilton (July Project 18, 2013), http://www.hamiltonproject.org/charts/probability_of_childrens_income_level_given_p arents_income_level [https://perma.cc/C7KQ-ZWRK].

98. Jim Tankersley, American Dream Collapsing for Young Adults, Study Says, as Odds Plunge that Children Will Earn More than Their Parents, WASH. PosT (Dec. 8, 2016), https://www.washingtonpost.com/news/wonk/wp/2016/12/08/american-dreamcollapsing-for-young-americans-study-says-finding-plunging-odds-that-children-earnmore-than-their-parents/?utm_term $=.4 \mathrm{a} 45 \mathrm{fa} 997891 \quad$ [https://perma.cc/M5C9-9T6F]. For further information on changes and trends in social mobility, see the following: Jonathan Vespa, U.S. Census Bureau, The Changing Economics and DEMOGRAPHICS OF Young ADULTHOOD: 1975-2016 (2017), https://www.census.gov/content/dam/Census/library/publications/2017/demo/p20579.pdf [https://perma.cc/BR2L-2XNR]; New Census Bureau Statistics Show How Young Adults Today Compare with Previous Generations in Neighborhoods Nationwide, U.S. CENSUS BUREAU (Dec. 4, 2014), https://www.census.gov/newsroom/pressreleases/2014/cb14-219.html [https://perma.cc/DE8M-LZ4P]; RAJ CHETTY ET AL., THE Opportunity Atlas: Mapping the Childhood RoOts of Social Mobility, 
American children, downward mobility is even bleaker: a black child born to parents in the top quintile is roughly as likely to fall to the bottom family income quintile as to remain in the top quintile, while, by contrast, a white child born in that same quintile is almost five times as likely to stay there as fall to the bottom one. ${ }^{99}$

As critical race theorists have argued, the intergenerational transmission of wealth is "integral to the future perpetuation of racial inequality across generations" in a number of ways: 1) "education, experiences, friendships, and contacts," including college tuition; 2) lifetime support, such as qualifying for a first home; and 3) gifting and inheriting assets. ${ }^{100}$ Moreover, the initial disadvantages of inheritance under slavery "became embedded in social institutions and transmitted across generations." 101

Financial assets are important to maintaining intergenerational wealth (although plenty of self-made billionaires exist) both because of the transmission of actual property ${ }^{102}$ and also because of the transmission of advantage. ${ }^{103}$ There is ample data to support the importance of such legacies. Intergenerational transfers (whether through gift or bequest) accounts "for at least 50\%-and perhaps more

OPPORTUNITY INSIGHTS (2018), https://opportunityinsights.org/wpcontent/uploads/2018/10/atlas_paper.pdf [https://perma.cc/8TL3-L752]; Richard Fry, Ruth Igielnik \& Eileen Patten, How Millennials Today Compare with Their Grandparents 50 Years Ago, PEW Res. CTR. (Mar. 16, 2018), http://www.pewresearch.org/fact-tank/2018/03/16/how-millennials-compare-with-theirgrandparents/ [https://perma.cc/7MUG-NU22].

99. RAJ CHETTY ET AL., RACE AND ECONOMIC OPPORTUNITY IN THE UNITED States: AN Intergenerational PersPeCtive 3 (2018), http://www.equality-ofopportunity.org/assets/documents/race_paper.pdf [https://perma.cc/9ZNY-GPZX].

100. R. Richard Banks, "Nondiscriminatory" Perpetuation of Racial Subordination Black Wealth/White Wealth, 76 B.U. L. REV. 669, 685-86 (1996) (book review).

101. Patricia Hill Collins, African-American Women and Economic Justice: A Preliminary Analysis of Wealth, Family, and African-American Social Class, 65 U. CIN. L. REV. 825 (1997).

102. See, e.g., PiKetTy, supra note 11, at 22, 246 (discussing the impact of inherited wealth).

103. See John H. Langbein, The Twentieth-Century Revolution in Family Wealth Transmission, $86 \mathrm{MiCH}$. L. REV. 722, 730 (1988) ("A central thesis of this article is that paying for education has become the characteristic mode of intergenerational wealth transmission for most American families."); Mark L. Ascher, Curtailing Inherited Wealth, 89 Mich. L. REV. 69, 90 (1990) (proposing "a system that allows (or even encourages) parents to use their material advantages to benefit their children through acculturation and education yet prohibits transfers of purely financial advantage"); Joshua C. Tate, Caregiving and the Case for Testamentary Freedom, 42 U.C. DAVIS L. REV. 129, 193 (2008) (exploring basis for testamentary freedom of disinheriting children); see also Daniel J. Amato, The Good, the Bad, and the Ugly: The Political Economy and Unintended Consequences of Perpetual Trusts, 86 S. CAL. L. REV. 637, 672 (2013) ("[E]state taxation creates significant inefficiencies by distorting economic decisionmaking."). 
than $80 \%$ - of the net worth of families in the United States." 104 Research on inter-generational mobility shows that parental income has an impact on both wealth and income. ${ }^{105}$ Household income is closely related to college attendance ${ }^{106}$ and graduation, ${ }^{107}$ and those "born to wealth" are much more likely to have college (or an advanced degree) and to work in a family business, another way of concentrating wealth. ${ }^{108}$

While transfers of $\$ 1,000,000$ or more constitute only about $2 \%$ of the actual number of transfers at death, they account for $40 \%$ of the total dollars transferred, and while over $70 \%$ of inter vivos gifts are less than $\$ 50,000$, the relatively few gifts in amounts exceeding $\$ 1,000,000$ account for almost half of the total dollars received. ${ }^{109}$ The median net worth of those gift and inheritance recipients is almost three times that of the median net worth of the population. ${ }^{110}$

As the Federal Reserve Board's website acerbically notes, "the bulk of intergenerational transfers are flowing to families that already have substantial resources," with the top $10 \%$ of households (by income) receiving more than one-third of intergenerational transfers (as

104. Aloni, supra note 8, at 26; see Osamudia R. James, Valuing Identity, 102 MinN. L. REV. 127, 159 (2017) (finding that the U.S. economy has failed "to support economic security and stability through any means other than intergenerational wealth transfer").

105. E.g., Ray Boshara, Born on 3rd Base? The Effects of Head Starts and College on Family Wealth, FED. RES. BANK ST. LOUIS (Apr. 17, 2018), https://www.stlouisfed.org/on-the-economy/2018/april/born-third-base-effect-headstarts-college-family-wealth [https://perma.cc/LS8J-P7FF] ("[T]he typical middle-aged families with the most 'favorable' inherited traits-white and college-educated parentshad three times as much income and six times as much wealth compared with the median family in the entire population.").

106. Raj Chetty et al., Where is the Land of Opportunity?: The Geography of Intergenerational Mobility in the United States (Nat'l Bureau of Econ. Research, Working Paper No. 19843, 2014), https://www.nber.org/papers/w19843.pdf [https://perma.cc/XB44-AP7F]; Richard V. Reeves \& Eleanor Krause, Raj Chetty in 14 Charts: Big Findings on Opportunity and Mobility We Should All Know, BrooKIngs INST. (Jan. 11, 2018), https://www.brookings.edu/blog/social-mobilitymemos/2018/01/11/raj-chetty-in-14-charts-big-findings-on-opportunity-and-mobilitywe-should-know/ [https://perma.cc/W7Y5-CE7Z].

107. V. Joseph Hotz et al., The Role of Parental Wealth and Income in Financing Children's College Attendance and Its Consequences (Nat'l Bureau of Econ. Research, Working Paper No. 25144, 2018), https://www.nber.org/papers/w25144.pdf [https://perma.cc/7QWV-BXW9].

108. Laura Feiveson \& John Sabelhaus, How Does Intergenerational Wealth Transmission Affect Wealth Concentration?, FED. RES. BD. (June 1, 2018), https://www.federalreserve.gov/econres/notes/feds-notes/how-does-intergenerationalwealth-transmission-affect-wealth-concentration-20180601.htm [https://perma.cc/ZK6K-4JCF].

109. Id.

110. Id. 
shown below), and the top $10 \%$ (by wealth) receiving more than $50 \% .^{111}$

Table 1. Concentration of Intergeneration Transfers Received by Income and Wealth ${ }^{12}$

\begin{tabular}{|c|c|c|}
\hline & Income by Income Group & Wealth by Income Group \\
\hline Bottom Half & $21 \%$ & $8 \%$ \\
\hline 50th to 90th Percentiles & $41 \%$ & $36 \%$ \\
\hline Top 10 Percent & $38 \%$ & $56 \%$ \\
\hline
\end{tabular}

Wealth begets more wealth. Consider that when someone has poor credit (a low, or no, credit score), this can impact both employment and housing options and also result in decreased access to various financial products and the highest rates for borrowing money. ${ }^{113}$

\section{Using the Preferences of the Wealthy?}

The statistics on who has wills are not surprising: those with higher incomes, those who are white, and those who are older. ${ }^{114}$ Examining the dispositions of wills provides insight into how those demographics-older, wealthier, whites-seek to dispose of their property. But those preferences may be skewed by that demographic.

In our admittedly small empirical study, in which we found little planning, we observed that the utility of wills depended not necessarily on wealth but instead on family structure and relationship. That is, families who got along sometimes ignored the decedent's wishes and distributed property as they deemed fair. ${ }^{115}$ That type of informal distribution may be what happens in the overwhelming majority of deaths that never make it to probate court. For example, of the more than 9000 deaths in 2016 in Pima County, Arizona (which includes

111. Id.

112. How Does Intergenerational Wealth Transmission Affect Wealth Concentration? Accessible Data, FED. RES. BD., https://www.federalreserve.gov/econres/notes/feds-notes/how-does-intergenerationalwealth-transmission-affect-wealth-concentration-accessible-20180601.htm\#fig520180601 [https://perma.cc/NGH2-ZL5Z].

113. Diana Elliott \& Ricki Granetz Lowitz, Urban InSt., What is the

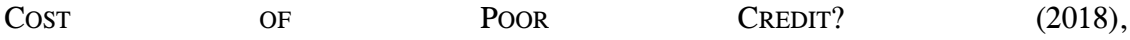
https://www.urban.org/sites/default/files/publication/99021/what_is_the_cost_of_poor_ credit.pdf [https://perma.cc/QDP5-8LY6].

114. Jeffrey M. Jones, Majority in U.S. Do Not Have a Will, GalluP (May 18, 2016), https://news.gallup.com/poll/191651/majority-not.aspx [https://perma.cc/LZG7-S4GQ].

115. Cahn \& Ziettlow, supra note 2, at 344-48. 
Tucson), less than $1 \%$ resulted in a probate filing. ${ }^{116}$ Part of this critique of the celebration of dead hand control, then, is not only that it gives control to the dead that the decedent may not necessarily have wanted (in light of the number of people who do not write wills), but also that it may be ignored by the survivors when it is contrary to their needs (particularly given the huge percentage of estates that stay out of probate court).

\section{MOVING FORWARD}

Asking the wealth question shows the impact of numerous trusts and estates doctrines on: (1) people of varying socioeconomic levels; (2) the need to adapt doctrine to address actual, rather than presumed, preferences; and (3) the benefits of drawing on alternative perspectives and experiences. This perspective shows us that decreasing economic inequality in America will require a series of large-scale policies. Some of them are familiar to trusts and estates scholars, such as increasing the marginal tax rate $^{117}$ and the estate and gift tax, ${ }^{118}$ or changing various doctrines. ${ }^{119}$ Others come from outside of the field, as discussed at the end of this Essay. ${ }^{120}$

I want to show how the wealth question applies in two contexts: wills for everyone and intestacy. Consider the underlying assumptions of each: does everyone really need a will, or should we work on improving the intestacy system? And do the intestacy rules reflect the

116. Fleming \& Curti, Take Our Survey (Mar. 3, 2019), https://perma.cc/3C8G-HKHB.

117. See, e.g., Paul Krugman, The Economics of Soaking the Rich, N.Y. TIMES (Jan 5, 2019), https://www.nytimes.com/2019/01/05/opinion/alexandria-ocasiocortez-tax-policy-dance.html [https://perma.cc/QV6S-4UM8]. In 1980, the top federal income tax rate was 70\%. See Federal Income Tax Brackets (Tax Year 1979), TAXBRACKETS.ORG, https://www.tax-brackets.org/federaltaxtable/1980 [https://perma.cc/VK29-PGAA].

118. See, e.g., Paul L. Caron \& James R. Repetti, Occupy the Tax Code: Using the Estate Tax to Reduce Inequality and Spur Economic Growth, 40 PEPP. L. REV. 1255, 1256 (2013).

119. These doctrines include:

(1) rules that interact with the tax-and-transfer system (e.g., the rule against perpetuities), (2) rules that govern relations between grantors and beneficiaries on the one hand and creditors on the other (e.g., spendthrift and asset protection trusts), (3) rules that govern relations between beneficiaries and trustees (e.g., fiduciary duties), and (4) rules that govern relations among beneficiaries (e.g., abatement, ademption, cy pres, and execution formalities).

Chang, supra note 10 , at 77.

120. See infra text at notes 137-38. 
preferences of the decedents who do not write wills? And then, this Part turns to solutions outside of the field.

\section{A. Trusts and Estates and the Wealth Question}

\section{WILLS FOR ALL}

There are numerous reasons to have a will, ${ }^{121}$ with the top reason most frequently consisting of some variation of testator control. But consider whether everyone needs to engage in such planning. Because outsider perspectives have caused us to see trusts and estates as not just focused on testator's intent, but also on the structure of wealth and the meaning of inheritance to different groups of people, wills may not be useful for individuals who would choose the intestacy result ${ }^{122}$ - or who prefer that surviving family members make decisions with relatively minimal guidance. ${ }^{123}$ Wills that enshrine dead hand control assume that the testator has some preference to express, some favored disposition that needs to be reinforced by a probate court. As a thought experiment, conjecture whether a decedent inevitably and always cares about asset disposition, or would want the survivors to do what they think is best, or might want to preserve family harmony by not making any such decisions. ${ }^{124}$ Studies of actual practices for estates that stay out of court, or are resolved without court challenge, may show the merely "precatory" nature of the testator's preferences. ${ }^{125}$ The cases that do appear in court represent a tiny percentage of the population that dies each year. ${ }^{126}$

While wills for everyone may not be an appropriate slogan, incapacity planning for everyone (somewhat clunkier) might be more appropriate. Adapting the initiatives in the wills context to ensure that individuals plan for their own capacity might be more helpful to ensure that wishes with respect to health care and financial planning are implemented.

121. See, e.g., Top Ten Reasons to Have a Will, FIndLAw, https://estate.findlaw.com/wills/top-ten-reasons-to-have-a-will.html [https://perma.cc/7WS4-AZWF].

122. Horton, supra note 55, at 341 ("[A] critic might question the decision to draw inferences about intestacy from dispositive choices in wills.").

123. For those who plan, a power of appointment performs this function by deferring decisionmaking to a trusted powerholder as do discretionary distribution trusts.

124. This critique of dead hand control thus asks the wealth question by drawing on actual experiences and preferences. See supra note 9.

125. Executors do have fiduciary responsibilities, of course. But only estates that go through probate court have such fiduciaries appointed.

126. See supra note 116 (discussing Pima County, Arizona). 


\section{INTESTACY RULES}

The intestacy rules are premised on the normative nuclear family, and they reflect the desires of many of those families. ${ }^{127}$ The UPC has steadfastly focused on marital relationships, not broadening provisions concerning intestacy, for example, to include civil unions or domestic partners. ${ }^{128}$ But the trends in nonmarriage, divorce, and short-term cohabitating unions have led to a wide assortment of stepfamilies and kin networks. ${ }^{129}$

Some aspects of the intestacy laws reflect these changes, such as the share left to a surviving spouse when either the decedent or the survivor have non-joint children, with the surviving spouse in such situations receiving a smaller share than where there are only joint children. ${ }^{130}$ But other parts of the intestacy laws have not been revised to reflect these new family structures. While this may be entirely appropriate-many nonmarital partners, for example, may not want their assets distributed to the other partner upon death through intestacy ${ }^{131}$-it may not reflect the realities of functional families. In their study, for example, Danaya Wright and Beth Sterner found that a majority of decedents who had stepchildren left property to them. ${ }^{132}$

$$
* * *
$$

Applying a wealth lens would result in challenges to other doctrines. Consider revocation upon divorce statutes, which serve a function in protecting allegedly forgetful testators. Yet such a doctrine protects only a certain part of the population, and is not useful for lowincome people who are not married and may have no revocablebeneficiary assets, ${ }^{133}$ thereby showing how the wealth lens affects the analysis.

127. See, e.g., Cahn \& Ziettlow, supra note 2, at 337-38 (small sample); Danaya C. Wright \& Beth Sterner, Honoring Probable Intent in Intestacy: An Empirical Assessment of the Default Rules and the Modern Family, 42 ACTEC L.J. 341 (2017).

128. UNIF. PRobAte CodE art. II (amended 2010).

129. See Paul taylor, The Next America: Boomers, Millennials, and the Looming Generational Showdown (2014); CARbone \& CAHn, supra note 83.

130. See Unif. Probate Code art. II; see also Susan N. Gary, Jerome Borison, NaOmi R. CAHn \& Paula A. Monopoli, Contemporary Trusts and ESTATES chs. 2-3 (3d ed. 2017) (discussing family inheritance rights).

131. See, e.g., June Carbone \& Naomi Cahn, Nonmarriage, 76 MD. L. REv. 55 (2017).

132. See Wright \& Sterner, supra note 127 , at 368.

133. See Naomi R. Cahn, Revisiting Revocation Upon Divorce?, 103 IowA L. REV. 1879, 1901 (2018). 


\section{B. Other Policies}

While trusts and estates law contributes to the intergenerational transmission of wealth (and corresponding inequality), the intergenerational transmission of wealth is not the sole culprit-or source-of challenging economic inequality. ${ }^{134}$ Consequently, it is useful to place reforms from within trusts and estates into a larger context that addresses wealth accumulation. ${ }^{135}$ Such approaches might include: 1) labor market policies that would contribute to a full employment economy; 2) universal access to health insurance; 3) free early childhood education and greater availability to subsidized, high quality child care, which could open up opportunities for children and their parents; 4) greater opportunities for retraining or returns to school, perhaps through community colleges, to give workers greater flexibility and resilience; and 5) a minimum income should be considered to provide any hope of greater individual and family security. ${ }^{136}$

But the core is still wealth, and the existence of increasing economic inequality is at least partially the result of intergenerational wealth transmission; that process of wealth transmission provides the context for much of our scholarship in this field. Yet it also means that we must be attentive to just "[h]ow well any area of law safeguards the historically disadvantaged," 137 including trusts and estates. Building on that core insight, we must also be attentive to just how any area of law reflects societal prejudices and, more fundamentally, how difficult it is to change that area without changing the surrounding context.

134. See George-Levi Gayle \& Andrés Hincapié, Which Persists More from Generation to Generation-Income or Wealth?, FED. RES. BANK OF ST. LOUIS (July 2016), https://www.stlouisfed.org/publications/regional-economist/july-2016/whichpersists-more-from-generation-to-generation-income-or-wealth\#5

[https://perma.cc/FZP4-MRYD] ("[P]olicies aimed at human capital enhancement, e.g., free preschool for everyone, may be as effective at combating inequality as those aimed at limiting the advantage of the wealthy, e.g., a policy of a high inheritance tax."). But see Feiveson \& Sabelhaus, supra note 108 ("[P]olicies that tax and redistribute intergenerational transfers have the potential to greatly shift wealth around the population.").

135. Of course, if more people earn more, then there is more work for the trusts and estates field.

136. See Naomi Cahn \& June Carbone, Red Families v. Blue Families 190-205 (2010); QUART, supra note 20, at 239-41; LOWREY, supra note 20; see also Dixon \& Suk, supra note 20 (noting that "many constitutional democracies . . . are actively considering, and passing, measures to increase investments in education and training, raise the minimum wage, [and] guarantee a universal basic income").

137. Crawford \& Infanti, supra note 13 , at 347. 